\title{
Semantic Information Processing of Physical Simulation Based on Scientific Concept Vocabulary Model
}

\author{
Chiaki Kino Non-member (Japan Atomic Energy Agency, kino.chiaki@jaea.go.jp) \\ Yoshio Suzuki Non-member (Japan Atomic Energy Agency, suzuki.yoshio@jaea.go.jp) \\ Hiroshi Takemiya Non-member (Japan Atomic Energy Agency, takemiya.hiroshi@jaea.go.jp)
}

Keywords : Data analysis system, Semantic information processing, Numerical simulation, Verification \& Validation, Information model

Recently, researchers must analyze ever-larger amounts of data because techniques of computer have higher performance. It is difficult to analyze whole data because of constraints of research resources. So, researchers must put analysis targets down to limited area. However, researchers often make oversights and have misunderstandings in the process.

We have been developing a system to annotate physical meanings for data aiming at supporting a choice of interested region from large scale numerical simulation data. The system is able to interpret physical meanings of result data output from a numerical simulation and annotate meaningful information. The system stores various data analysis processes to interpret physical meanings and to annotate meaningful information from a scientific viewpoint. Researchers can choose an interested region by using the meaningful information suggested by the system. To actualize the system, we need establish a methodology to make a system recognize physical meanings.

So far, methodologies using knowledge processing, data mining or phase analysis have been proposed in order to extract physical meanings from the numerical simulation data. It can be said that these methods are able to express simple physical meanings, such as a vortex, proton-hydrogen atom collision and so on. However, existences of vortices or proton-hydrogen atom collisions are not all that researchers want to know. Even if vortices exist in a region, it's not meaningful information in the case of the predictable phenomena from previous knowledge. Whether an extracted physical phenomenon is meaningful or not depends on "when", "where" and "how" the phenomena exist. Namely, it depends on physical meanings of the phenomena in the broad sense. Therefore, we need a framework to describe the physical meanings.

We have been proposing Scientific Concept Vocabulary (SCV) that is a framework to numerically treat physical meanings. The basic idea of SCV is that physical meaning is described by combination of scientific concepts. Since the vocabularies are defined by substantial information (for example, numerical data, algorism and so on) to express the concept, a system is able to numerically treat abstract concepts. The description manner of $\mathrm{SCV}$ is similar to RDF (Resource Description Framework) that is composed of subject resource, object resource and property.

In this paper, we discussed about an information model to interpret physical meanings of numerical simulation result and display meaningful information.

Firstly, we discussed about scientific knowledge and proposed Scientific Knowledge Model that consists of Analysis Target, Scientific Index, Scientific Status and Scientific Perception in order to establish the model (Fig.1). Additionally, we showed that Scientific Perception is most meaningful information to solve problems or tasks.

Secondly, we proposed Scientific Concept Vocabulary model that is a framework to compose physical meanings, such as Analysis Target, Scientific Index, Scientific Status and Scientific Perception. The vocabularies are able to express physical meanings by combination of vocabularies that indicate concepts. The vocabularies equip substantial data and method to numerically treat concepts. This enables a system to numerically process concepts and to generate and interpret physical meanings.

Thirdly, we proposed Scientific Perception Frame that is a methodology to translate extracted Scientific Perception to a format which human can understand intuitively, such as natural language. In the present study, we examined 2 types of Scientific Perception, namely "Measurement"and "Detection".

Finally, we designed vocabularies and system configuration and applied to actual numerical simulation data. The present result shows that the present model enables a system to interpret physical meanings of numerical simulation result and display "break-up of liquid film" that is meaningful information from a viewpoint of nuclear power engineering (Fig. 2). Therefore, we can say that Scientific Concept Vocabulary model is able to describe meaningful information and Scientific Perception Frame is able to annotate them in a readable format. In the future, we will extend Scientific Concept Vocabulary in order to describe wider Scientific Perception.

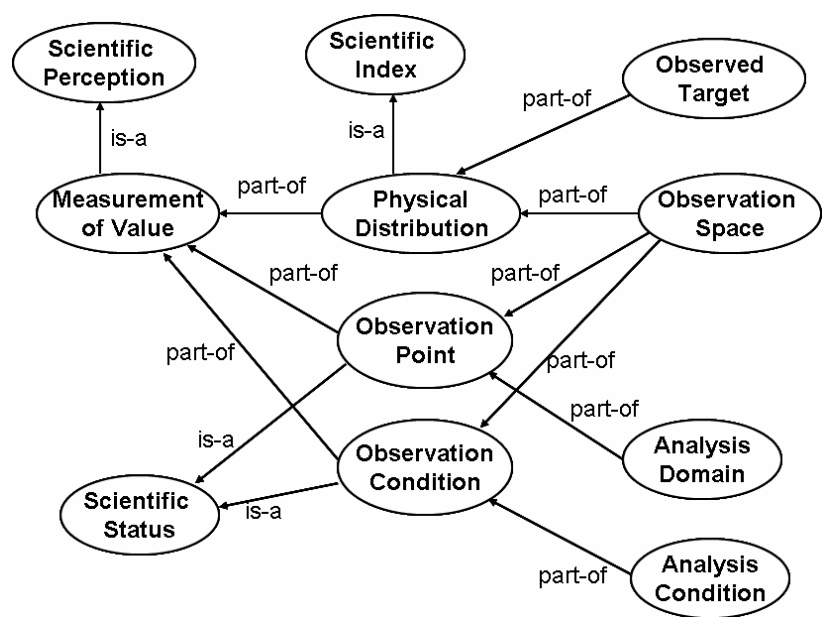

Fig. 1. Example of Ontology for Scientific Perception in the case of "Measurement of Value"

$$
\begin{aligned}
& \text { Most Break of Thickness is detected in midstream region } \\
& \text { percentage of total : } 0.53754 \\
& \text { start point of midstream }(\mathrm{x}, \mathrm{y}, \mathrm{z})=0.046725,0.041475,0.023625 \\
& \text { end point of midstream }(\mathrm{x}, \mathrm{y}, \mathrm{z})=0.046725,0.041475,0.048375
\end{aligned}
$$

Fig. 2. Analysis result output from CDAS 


\section{科学概念語彙モデルを用いた \\ 物理シミュレーションにおける意味情報処理}

非会員 木野 千晶* 非会員 鈴木 喜雄*
非会員 武宮 博*

\section{Semantic Information Processing of Physical Simulation Based on Scientific Concept Vocabulary Model}

Chiaki Kino*, Non-member, Yoshio Suzuki*, Non-member, Hiroshi Takemiya*, Non-member

Scientific Concept Vocabulary (SCV) has been developed to actualize Cognitive methodology based Data Analysis System: CDAS which supports researchers to analyze large scale data efficiently and comprehensively. SCV is an information model for processing semantic information for physics and engineering. In the model of SCV, all semantic information is related to substantial data and algorisms. Consequently, SCV enables a data analysis system to recognize the meaning of execution results output from a numerical simulation. This method has allowed a data analysis system to extract important information from a scientific view point. Previous research has shown that SCV is able to describe simple scientific indices and scientific perceptions. However, it is difficult to describe complex scientific perceptions by currently-proposed SCV. In this paper, a new data structure for SCV has been proposed in order to describe scientific perceptions in more detail. Additionally, the prototype of the new model has been constructed and applied to actual data of numerical simulation. The result means that the new SCV is able to describe more complex scientific perceptions.

キーワード : データ解析システム, 意味情報処理, 数值シミュレーション, 妥当性検証, 情報モデル

Keywords : Data analysis system, Semantic information processing, Numerical simulation, Verification \& Validation, Information model

\section{1. 緒言}

近年，計算機技術の大幅な向上により，大規模・複雑な 数值シミュレーションの実施が可能となり，数值シミュレ ーションの果たす役割も年々大きくなっている。最近では ペタスケールのシミュレーションを可能とする計算機の開 発も進んでおり ${ }^{(1)}$, 今後数值シミュレーションで扱うデータ 量はさらに増大寸ることが予想される。しかし，解析に使 用できる研究資源には限界があることから，大規模・複雑 な数值シミュレーション結果全体を精査することは困難と なってきている。

従来, このような大規模数值シミュレーション結果を扱 う場合, 結果データの中から科学的に興味のある領域 (Region of Interest : ROI) を研究者の判断で限定することで 対応してきた。しかしながら，興味のある領域を選択する

* 日本原子力研究開発機構 システム計算科学センター 干110-0015 東京都台東区東上野 6-9-3 住友不動産ビル 8 号 館 8 階

Japan Atomic Energy Agency/Center for Computational Science and e-Systems (CCSE)

6-9-3, Higashi-Ueno, Taitou-ku, Tokyo 110-0015
過程において見落としなどのヒューマンエラーが発生する 可能性が否めず, 結果的に数值シミュレーションを用いた 研究の信頼性を大きく損なう要因の一つとなっている。

このような困難を克服するために，数值シミュレーショ ン結果より物理的・工学的に重要な情報を発見・抽出する データ解析システム (Cognitive methodology based Data Analysis System: CDAS) の開発を進めている(2)(3)。このシス テムは実行したデータ解析プロセスの物理的・工学的意味 を解釈し, その解析結果の中から物理的・工学的に重要と 判断された情報を提示することを目標としている。このシ ステムを用いることで, 従来以上に多角的な視点でデータ 解析を実施することができる。結果, 研究者による科学的 に重要な領域の選択をサポートし, ヒューマンエラーなど の低減が期待される。

システムがデータ解析プロセスおよびその解析結果の持 つ物理的・工学的な意味情報を認識するには, 意味情報を 数值的に扱うためのフレームワークが必要となる。しかし, 意味情報は極めて抽象的かつ複雑な構造を持っているた め, その意味情報の構造を詳細に分析し, 数值的な定義を 
可能とする情報モデルを構築しなくてはならない。

現在，著者らは科学概念語彙 (Scientific Concept Vocabulary: $\mathrm{SCV})$ を用いた情報モデルを開発している(4)。本モデルは物 理的意味をシステムが数值的に扱えるようにするため，全 ての実体データおよび処理プロセスの物理的意味がオント ロジー上で定義されている。このオントロジー上で定義さ れた実体データ・処理プロセスを用いてデータ解析プロセ スが構築される。このデータ解析プロセスを用いることに よりシステムはデータ解析結果の物理的意味をオントロジ 一的に認識することができる。

これまでに，本モデルを用いて数值シミュレーションデ 一タやその解析手法に物理的意味を付与寸ることで, 1 次元 速度分布, 2 次元壁面液膜厚さ分布といった科学的指標が記 述可能であることを示し，その科学的指標を利用して燃料 棒周辺に「液膜破断が存在する」といった科学的に有用な 情報の抽出が可能であることを示した。

しかし, 現状の科学概念語彙モデルで記述可能な科学的 知見は極めて単純かつ一部の情報に過ぎない。例えば「液 膜破断が存在する」という情報においても，どこに存在す るのか，それはどの程度存在するのかなどの情報が無けれ ば，科学的な考察を深めるための情報としては不十分であ る。現状の科学概念語彙モデルはこのような科学的知見を 構成するのに十分なデータ構造が確立されていない。よっ て, 本論文では科学的知見に関する考察を深め, より詳細 かつ複雑な科学的知見情報に対応したデータ構造を提案す る。さらに，そのデータ構造を用いて知見情報を生成する ための方法論を提案する。

\section{2. 科学概念語彙モデル}

この章では物理的意味情報を数值的に扱うフレームワー クである科学概念語彙モデルの概要について述べる。

〈2·1〉 オントロジーによる意味表現オントロジー とは概念と関係性に基づいて個物や現象を記述したもので ある。オントロジー上で定義された概念は，他の概念との 関係性からそのオントロジー上における位置づけが明確と なる。本研究では, ある概念が他の概念との関係性を確立 した状態にある時（すなわち，オントロジー上で概念が定 義された時)，その概念が「意味」を持つと定義する。

現実世界において人間が処理対象としているものは，才 ントロジーによって定義された概念のインスタンス化され たもの（実体）である。この実体はオントロジー上の概念 に基づいて生成される。よって，そのオントロジー上の概 念の性質（例えば，他の概念とどのような関係性を持って いるか，どのような属性を持っているかなど）をそのまま 受け継ぐ。すなわちオントロジー上の概念は実体のクラス となっていると言える。

この実体は必ず具体化された何らかの情報を持たなくて はならない。本研究では概念の実体を表す具体的な情報を 実体データと呼ぶ。人間の場合, 実体データとしては文字・ 画像・音など多様なデータ形式が利用できる。しかし，シ
ステム的に実体を扱う場合は数值データに限られる。本研 究では，オントロジー上で定義された概念をシステムが扱 えるデータ形式でインスタンス化するためのフレームワー クとして科学概念語彙モデルを提案する。

\section{〈2·2〉 科学概念語彙（リソースとプロパティ）}

科学概念語彙モデルはオントロジーを構成する「概念」 と「関係性」をインスタンス化し, システム上で数值的に 処理するために, 次に示す 2 種類のツールを用意する。こ れらのツールの名称は, これまでに研究・開発されてきた $\mathrm{RDF}^{(5)} \mathrm{OWL}^{(7)}$ にならって,「リソース」と「プロパティ」 と名付ける。本モデルではこれらを科学概念語彙と呼ぶ。

リソースは概念をインスタンス化するためのツールであ り, 概念ラベル, 実体データ, メソッドから構成される。 概念ラベルはオントロジー上の概念によって生成された各 インスタンスを識別するための情報である。実体データは 概念を表現する具体的な数值データである。全てのリソー スは必ず一つオントロジー上の概念というクラスに所属し ている。リソースの実体データはその所属クラスによって 規定されることになる。さらに，この実体データは結合す る他のリソースの実体データを用いて生成される。この実 体データを生成するための処理アルゴリズムがメソッドで ある。

プロパティは関係性をインスタンス化するためのツール であり, リソース間のデータ転送インタフェースの役割を 持つ。二つのリソースは必ず一つのプロパティによって結 合している。プロパティは指定されたリソースから実体デ 一タを抽出し, もう一方のリソースへ入力する機能を備え る。抽出される実体データは結合している二つのリソース が所属するクラスから判断される。

Figure 1 には科学概念語彙モデルの模式図を示す。ここで は二つのリソース A, B が示されており, リソース A は「物 理量」概念の「温度」という実体であり, リソース B は「物 理量分布」概念の「2 次元物理量分布」という実体である。 リソース A は概念ラベルとして温度, 実体データとして物 理量と物理量単位, メソッドとしてデータファイルを読み 込んで物理量・物理量単位を設定するアルゴリズムを持っ ている。リソース B は概念ラベルとして物理量分布, 実体 データとして物理量が測定された領域情報, メソッドとし て, 測定範囲を設定するアルゴリズムと 2 次元平面におい て物理量を測定するアルゴリズムを備えている。

Figure 1 の場合, プロパティ（Target）はリソース A にお ける実体データ (物理量) を抽出するように定義されてい る。リソース B のメソッドはこの抽出された実体データを 用いて, リソース B が持つ概念を定義する実体データを生 成する。

〈2·3〉科学概念語彙を用いた意味の構成 科学概念 語彙による意味の構成の例を Figure 2 に示す。「ある領域に おける物理量 2 次元分布を測定する」というメソッドを持 ったリソース $(\mathrm{A})$ にある領域」として「壁面」概念を示す リソース(B)が，「物理量」として「圧力」概念を示すリソー 
ス(C)が結合しているとする。リソース(A)単体で見れば，単 なる「ある領域における物理量 2 次元分布を測定する」と いう概念しか持たない。しかし，ある領域が「壁面」であ り，物理量が「圧力」であることが明確になれば，リソー ス(A)には「壁面における圧力分布を測定している」という 物理的意味が生成される。さらに，「壁面」概念リソースが 持つ「壁面が存在している領域情報」および「圧力」概念 リソースが持つ「圧力の物理量分布情報」を利用すること で「壁面における圧力分布」に関する具体的な実体データ

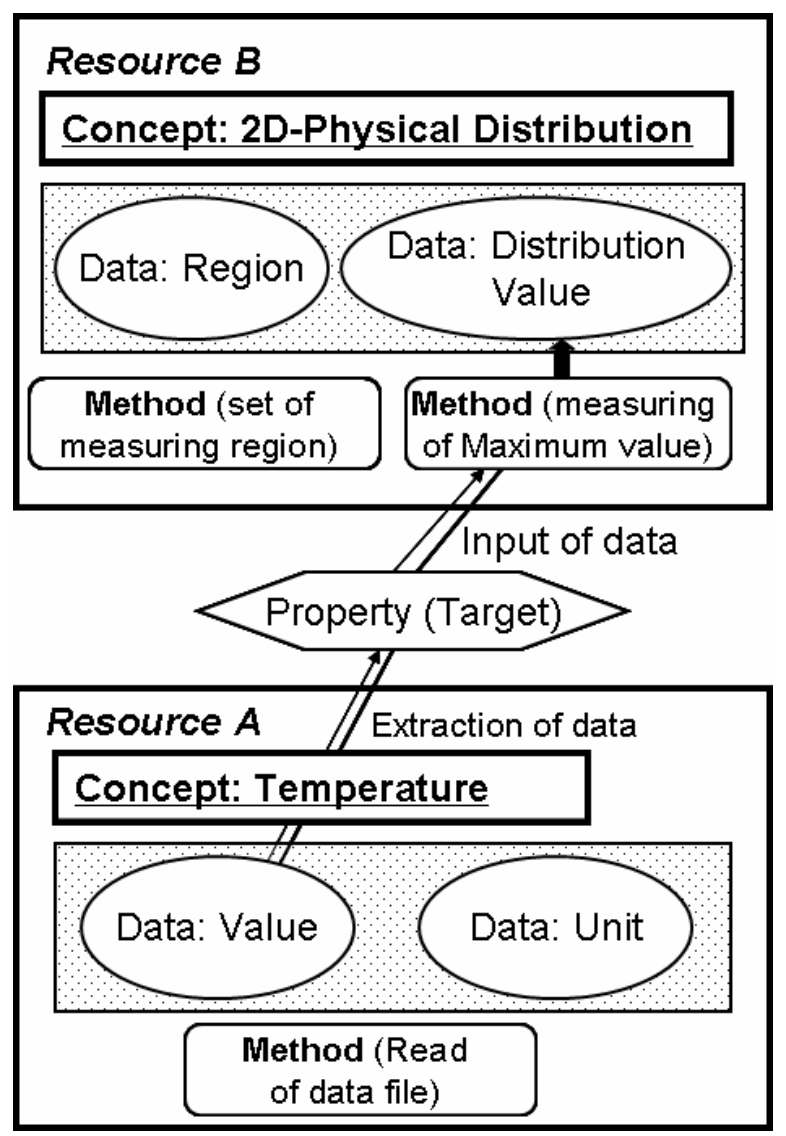

Fig. 1. Diagram of Scientific Concept Vocabulary Model

\begin{tabular}{|l|}
\hline Physical_Distribution \\
[data:1] 2D-distribution of Physical value \\
[data:2] Physical unit
\end{tabular}

(A)

Physical_Distribution:2D_Distribution

(B)
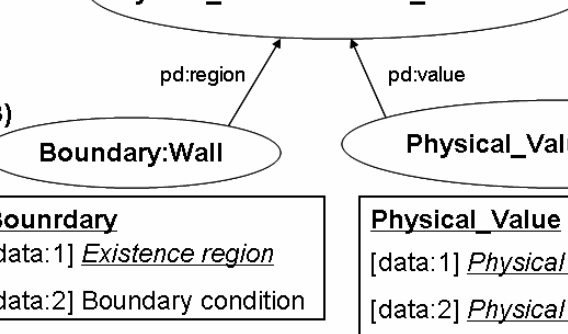

(C)

Physical_Value:Pressure

Physical_Value

[data:1] Physical value distribution [data:2] Physical unit

Fig. 2. Semantic information described by Scientific Concept Vocabulary
をシステムは数值的に認識（実体データを生成・保持）す ることができる。

この「圧力」概念を「せん断応力」概念に取り替えるこ とで「壁面におけるせん断応力分布測定」という新しい意 味を構成することができる。さらに「壁面」概念を「領域 A」 に取り替えれば「領域 A におけるせん断応力分布測定」と いう意味が構成できる。このように各リソースをデータ型 とメソッドにより規定されたモジュールとして扱うこと で, 概念の組み合わせによって様々な意味を構成していく ことが可能となる。これにより高度な記述力を実現する。

$\langle 2 \cdot 4\rangle$ 科学概念語彙の記述形式 科学概念語彙の記 述形式としては RDF や OWL に代表されるネットワーク的 情報記述モデルを採用する。 RDF ではリソースを「Web 上 で識別できるもの」として定義しているが, 科学概念語彙 におけるリソースは先に述べたように「概念のインスタン スを表現するために，システムにおいて具体的に実装され た概念ラベル・実体データ・メソッド」を示すものである。 よって, 科学概念語彙では各ノードを表現するために, scv:Description という形の修飾名を用いる。

また, 科学概念語彙では全てのリソースを URN (Uniform ResourceName) ${ }^{(8)}$ によって識別する。リソースが持つデータ 型およびメソッドは各リソースに定義されたURNによって 指定されている。システムはこの URN 情報を読み取ること で, 対応する処理を実施する。この URN は以下の規則に従 って決定される。

$<$ URN $>$ ::= "urn:" < Class name > ":" <Concept name > ":" < ID $>$

今回の科学概念語彙は CDAS 内でのみ使用されることを 前提としているため名前空間は省略している。この規則で は，まずリソースが所属するオントロジー上の概念名（ク ラス名）が指定され，その次にリソースが持つ概念ラベル 名が指定される。クラスとインスタンスの関係は OWL によ って別に記述することも可能であるが, URN にクラス情報 を含ませることによって, URN と具体的な処理を対応させ るプロセスを簡潔にすることができる。

さらに，例えば同じ「せん断応力 2 次元分布測定」とい う同じ概念ラベル・実体データ・メソッドを持つリソース においても，指定される領域においてそのリソースが持つ

$1<$ scv:Description rdf:about="urn:Physical_Distribution:2D_Distribution">
2

3

4

5

$6</$ scv:Description $>$
Fig. 3. Example of Description by SCV 
意味は異なるため, それらは区別されなければならない。 <ID >を指定することで，同種の意味を持った複数のリソー スも識別されることができる。Figure 3 に記述例を示す。

\section{3. 科学的知見モデル}

この章では科学研究で必要となる科学的知見をモデル化 し, システムが扱う物理的・工学的情報の種類・性質を考 察する。

〈3.1〉 科学的知識の構造科学的知識とはこれまで の科学研究を通じて得られた, 具体的な行動（設計の変更 や課題の解決策など） へと結びつき得る物理的・工学的な 情報の集合体である。例えば，「ある条件下において壁面 A の地点 X に最大温度が発生し, その最大温度が材料の融点 を超えている」という情報が得られれば，別の材料を用い る, 構造を変化させるなどの具体的行動に結びついていく。 よってこれは科学的知識といえる。この科学的知識を集積 していくことで科学が発達していくと言える。

先に述べた科学的知識は「ある条件下において壁面 A の 地点 X に最大温度が発生している」,「最大温度が材料の融 点を超えている」といった物理的・工学的に特徵的な情報 を統合することで得られている。この科学的知識を構成す るために必要な物理的・工学的意味を伴った情報が科学的 知見である。実際の科学的知識は複数の科学的知見情報そ れぞれを比較・統合することによって構成される。

〈3.2〉科学的知見の構造 科学的知見亡は自然現象 から抽出された様々な定量的・定性的特徵に関する情報で ある。さらに突き詰めれば, それら特徴の背景に存在する 自然法則を見出すための情報である。すなわち, 科学的知 見には, 全ての現象が因果関係の上に成立しているという ことを前提とし, その定量的・定性的特徵をもたらす要因 を見出すための情報が含まれていなくてはならない。

本研究において科学的知見は, 科学的指標と科学的状態 を分析することで生成される情報と定義される。すなわち, 自然現象を再現した数值シミュレーションや実験データか ら, 物理量分布のようなある観点に沿って抽出された物理 的に有意味なデータ（科学的指標）を設定し, 様々なデー タマイニング手法, 統計処理手法, 実験值や理論值との比 較などを実施することで，その指標から定量的・定性的特 徵を抽出する。最後に, その定量的・定性的特徴の要因々 なり得る観測条件や周辺環境に関する情報（科学的状態） を明確にすることで, 科学的知見を構成するものとする。

この科学的知見は大きく 2 種類, 寸なわち「測定」と「発 見」に分類することができる。「測定」とは科学的指標とし て物理量分布を想定しており, 物理量分布の最大值, 最小 值, 平均值, 近似関数などの特徵量を抽出することで生成 される。「発見」とは科学的指標として物理現象（例えば, 渦や気泡など）を想定しており, 物理現象が存在する領域 を抽出することで生成される。

先にあげた「ある条件下において壁面 $\mathrm{A}$ の地点 X に最大 温度が発生している」という科学的知見の場合, 「ある壁面
上の温度分布」という科学的指標から最大温度を測定し， 「材料の融点」という判断基準より高い領域を発見すること によって構成されていると言える。また,「ある条件下」と いう科学的状態に関する情報を利用することでこの科学的 知見が構成される。

〈3.3〉科学的指標の構造科学的指標とは「ある観 測対象の, ある観測空間における時空間分布情報」と定義 される。観測対象とは主に「速度」や「温度」などの物理 量分布および「渦」や「気泡」などの物理現象が想定され る。観測空間とは観測された条件・領域を定義するもので あり, 単なる時刻・領域の設定に加えて, どのような解析 体系であるか（例えば, 流路や流れ場の境界条件, 周辺の 環境条件), どのような流体・材料を用いているか（例えば 流体の物性值や材料の特性) など, 系全体が持つ広範な概 念を含んでいる。

数值シミュレーションや実験の測定結果には多種多様な 情報が含まれているが, それらの情報の中からこの科学的 指標を抽出するプロセスが科学研究の基本的な作業とな る。実際の科学研究においては「物理量分布」や「物理現 象」の観測という方法論を用いて科学的指標を得ることに なる。

〈3.4〉科学的状態の構造 科学的状態とはある定量 的・定性的特徵を含んだ科学的指標が観測された時, その 観測領域がどのような特徽をもっているかを示した情報で ある。定量的・定性的特徵をもたらす要因となり得る科学 的状態は大きく 2 つの種類に分類できる。流入量や周辺圧 力, Reynolds 数などの物理パラメータなど, 系全体に影響 を及ぼす大局的要因と, 現象が発生している時刻や地点な ど局所的要因である。本研究ではこれら要因となり得る情 報を, 大局的情報を設定する解析条件的特徵と, 局所的情 報を設定する時空間的特徵に集約して取り扱うこととす る。

よって, 科学的状態は大局的情報として「観測条件」を, 局所的情報として「観測位置」を持つ。これらは科学的状 態のサブクラスとして定義される。「観測条件」は観測され たデータの解析条件に関する情報であり,「流入速度」や 「壁面熱流束」などが考えられる。「観測位置」とは解析体 系における位置関係に関する情報であり，例えば「流入口 からの距離」や「壁面からの距離」などが考えられる。

〈3.5〉科学的知見オントロジー これまでの考察を 基に構築した科学的知見オントロジーを Figure 4 に示す。ま ず, 科学的知見は科学的指標と科学的状態によって構成さ れる。さらに, 科学的指標はそのサブクラスとして「物理 量分布」や「物理現象」を持ち, それらは「観測対象」と 「観測空間」によって構成される。科学的状態はそのサブク ラスとして「観測位置」・「観測条件」を持ち，「観測位置」 は「観測空間」と「解析体系」によって,「観測条件」は「観 測空間」と「解析条件」によって構成される。

科学的知見には測定される対象に応じて,「值の測定」 「形状の測定」「近似関数の測定」などのサブクラスが考え 


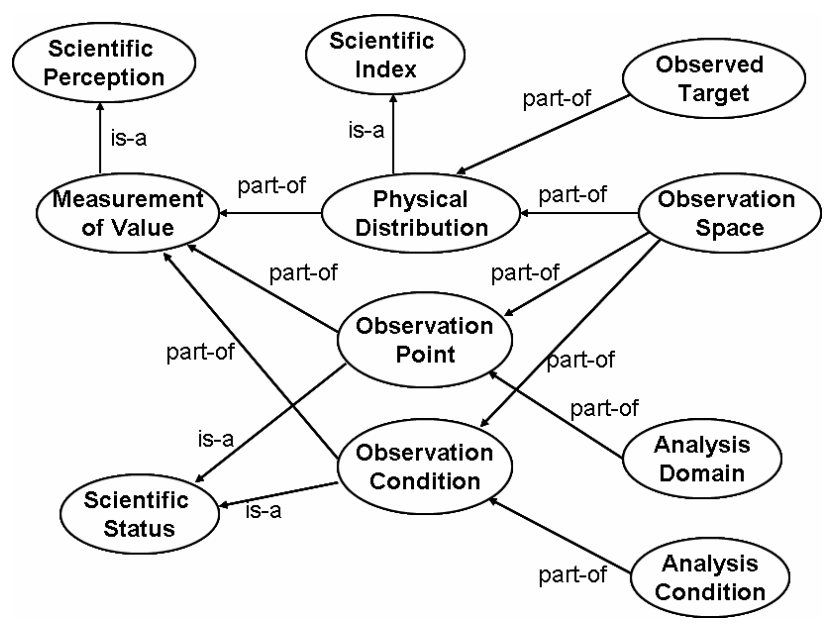

Fig. 4. Example of Ontology for Scientific Perception in the case of "Measurement of Value"

られる。Figure 4 に示した「值の測定」に関する科学的知見 の場合, 科学的指標として「物理量分布」が結合している。 また，「発見」に関する科学的知見を構築する場合は科学的 指標として「物理現象」が結合することになる。

\section{4. 科学的知見の構成}

本章では科学的知見を構築するために必要な，科学的指 標, 科学的状態, 定量的・定性的特徵を表現するためのデ 一タ構造に関して述べる。さらに，これらのデータ構造を 利用して知見情報を生成し，ユーザに表示するための具体 的方法である知見フレームについて述べる。

〈4·1〉科学的指標のデータ構造 科学的指標は物理 量分布・物理現象を想定し，以下のデータ構造を備えてい る。

（1）観測領域情報

(2) 観測結果

(3) 観測対象概念ラベル

(4) 観測空間概念ラベル

観測領域情報とは，全空間において物理量分布や物理現 象の有無を観測した領域に観測番号を割り当てることで生 成される領域情報である。物理現象は基本的に 3 次元が想 定されるが，物理量分布は 1 次元分布， 2 次元分布， 3 次元 分布などが存在する。今回定義した科学的指標では，これ らを全て同じデータ型で取り扱う。すなわち，観測番号の 分布によって, 結果的に 1 次元分布や 2 次元分布が表現さ れる。

観測結果は観測された領域における観測対象の量・存在 および物理量単位に関する情報である。物理量分布の場合 は観測された量の分布情報が保持される。物理現象の場合 は物理オブジェクト型のデータを用いる。物理オブジェク 卜型とは物理現象が存在する領域に物理オブジェクト番号 を付与することで物理現象が存在する領域を示すデータ型 である。

観測対象概念ラベル，観測空間概念ラベルは結合した観
測対象リソースおよび観測空閒リソースが持つ概念ラベル をそのまま保持する。例えば, 科学的指標として「2 次元物 理量分布」, 観測対象として「温度」, 観測空間として「壁 面」が設定されている場合, 観測対象概念ラベルは「温度」, 観測空間概念ラベルは「壁面」が設定される。以上より，「2 次元物理量分布」という科学的指標は「壁面上の 2 次元温 度分布」という物理的意味を保持することが可能となる。

〈4·2〉科学的状態のデータ構造科学的状態は観測 条件および観測位置に関する情報を想定している。

観測条件情報は以下のデータ構造を備えている。

(1) 解析条件概念ラベル

（2）物理条件情報

解析条件概念ラベルは結合している解析条件（例えば，流 入条件や壁面温度条件など）の概念ラベルをそのまま保持 する。また, その具体的な物理条件（例えば, 流入速度 $\mathrm{V}_{\text {inlet }}=1.0 \mathrm{~m} / \mathrm{s}$ や壁面温度 $\mathrm{T}_{\text {wall }}=100^{\circ} \mathrm{C}$ など）もそのまま保持 される。物理条件情報は「対象概念」「不等号」「基準值」, 「物理量単位」によって構成される。流入速度条件の場合で あれば,「対象概念」として「流入速度」,「不等号」として 「等しい」,「基準値」として「1.0」,「物理量単位」として $\lceil\mathrm{m} / \mathrm{s} 」$ という情報を保持する。

観測位置情報としては「基準対象物からの距離」および 「観測領域の物理的・工学的意味」という 2 種類の形式が想 定される。前者は例えば「壁面からの距離」などであり, 後者は「上流域・中流域・下流域」などである。

「観測位置の基準対象物との位置関係」の場合は以下のデ 一タ構造を備えている。

（1）基準対象物概念ラベル

（2）距離分布情報

基準対象物概念ラベルは位置関係の基準となる対象物（例 えば，流入口や壁面）が持つ概念ラベルをそのまま保持す る。また, その基準対象物が存在する領域までの最小距離 を観測領域全体で算出し, 距離の空間分布情報として保持 する。これにより，流入口や壁面との位置関係という物理 的意味を保持することができる。

「観測位置の物理的意味」の場合は以下のデータ構造を備 えている。

(1) 観測位置概念ラベル

（2）意味分布情報

観測位置概念ラベルは「上流域」や「下流域」など結合す る観測領域に設定された概念ラベルがそのまま保持され る。その概念が設定された領域情報が意味分布情報として 保持される。これにより,「上流域・中流域・下流域」など 各領域における物理的意味を保持することができる。

〈4·3〉 定量的・定性的特徵のデータ構造 科学的知 見は測定・発見を想定し，以下のデータ構造を持っている。

（1）定量的・定性的特徵情報

（2）観測条件情報

（3）観測位置情報

定量的・定性的特徵に関しては抽出される特徵量に応じ 
てデータ型が異なる。「值の測定」のデータ型であれば定数 型が採用される。定数型の特徵情報として, 1 次元分布の場 合, 最大值, 最小值, 平均值を対象としたデータ型である。 2,3 次元分布の場合, 最大值, 最小值, 平均值, 極值, 鞍 点を対象とする。

1 次元分布を対象とした「近似関数の測定」の場合，近似 関数型が採用される。このデータ型は分布形状の近似関数 を求めることで, 近似関数の次数, 増加・減少, 周期性を 対象としたデータ型である。

また，「発見」の場合は物理オブジェクト型のデータ型が 採用される。物理オブジェクト型とは先に述べたように， ある物理的特徵を持った領域を物理オブジェクトとして抽 出するためのデータ型である。例えば，気泡オブジェクト が複数存在し, それらの中で互いに近接している気泡を対 象とする場合，「接近している気泡」という新たな物理現象 を定義し，その「接近している気泡」が存在する領域に物 理オブジェクト番号を設定することで物理現象が存在して いる領域情報を生成する。

同時に，定量的・定性的特徵が観測された時刻・領域の 観測条件情報と観測位置情報を抽出し保持する。これらの 情報は結合している科学的状態リソースの情報をそのまま 利用寸る。

〈4・4〉 知見フレーム 特徵情報をどれだけ抽出して もそれらが無秩序に保持されているだけでは, 重要な知見 を得ることは難しい。なんらかの規則に則って特徵情報が 整理・統合されることにより，科学的知見情報として利用 することができる。

本モデルでは特徵情報を整理して科学的知見情報を生成 するために，知見フレームという手法を提案する。この知 見フレームはある知見を生成するために必要な特徽情報を 挿入するためのスロットによって構成されている。各スロ ットに挿入可能な特徵情報タイプは特定のデータ型に限定 されている。科学的指標・状態から抽出された特徵情報の データ型がスロットに挿入可能なデータ型と一致する場 合，そのスロットに挿入され，知見情報が生成される。

今回提案する知見フレームは二種類であり，一つは量・ 性質に対する「測定」に関するものであり，もう一つは何 らかの特徴情報に対する「発見」に関するものである。「発 見」は存在の有無を判定する情報であるが，何かが存在す る以上その存在の個数・存在範囲という情報を常に備えて いることから，その存在の多寡に関する情報も本質的に備 えている。よって,「発見」とは存在の有無および存在の多 臭が評価された情報である。

例えば, 1 次元分布の最大值や平均值などは「測定結果」 として報告される。「気泡」や「液膜破断」などの物理現象 は存在の有無が評価され, 「発見」された場合その情報が報 告される。物理現象の場合はその個数も計測され, 存在の 多臭に関する情報として報告される。さらに知見フレーム は時刻，領域，初期条件などに関するスロットも持ち，そ れらの現象が発生した要因となり得る情報として知見情報
に含める。以下に知見フレームの例をいくつか示す。

（1） ある地点における, ある概念の定量的・定性的特徵 （ここでは最大值）に関する「測定結果」知見情報の構成フ レーム

Max of [(A) Concepts] is [(B) Observation Result for Maximum value] at [(C) Point $]$

(A)の特徵スロットには知見情報の対象となる概念ラベルが 挿入される。例えば「速度 1 次元分布」や「せん断応力 2 次元分布」が挿入される。(B)の特徵スロットには抽出され た最大值の数值が挿入される。(C)の特徵スロットには最大 值が存在する地点が挿入される。以上から,「[(A)速度 1 次 元分布 $]$ の最大值は [(C)ある地点 $]$ における $[(\mathrm{B}) * *]$ で ある」という知見情報が得られる。

（2）ある特定領域においてある概念が最も多く「発見」 されたという知見情報の構成フレーム

Most of [(A) Concepts] is detected in [(B) Specific Region]

(A)の特徵スロットには知見情報の対象となる概念ラベル, すなわち「気泡」や「液膜破断」などの物理オブジェクト 型の概念名が挿入される。(B)はその物理オブジェクトが最 も多く存在する特定領域に関する情報が挿入される。以上 から，「最も多くの [(A)気泡] が [(B)**領域] で発見さ れた」という知見情報が得られる。

〈4·5〉 システム構成 Figure 5 に科学概念語彙を用 いたデータ解析を実現するためのシステム構成を示す。本 システムは以下の 5 つの層 (Cognitive 層, Query 層, Message 層, Application 層, Visualization 層) で構成されている。

Cognitive 層 : ユーザによって科学概念語彙を用いて記述さ れた解析対象, 解析条件に関するファイルをパーサによっ て読み取り, データ解析プロセスを構成するための機能を 提供する。データ解析プロセスの構成に必要な手法・知見 などは Query 層に問い合わせる。この時, Cognitive 層はリ ソースが持つ結合情報を組み合わせて科学的意味を構成し 把握する。

Query 層 : Cognitive 層からの問い合わせに対応し, データ ベースに蓄えられたデータ解析プロセスから実行可能なプ ロセスを検索・選択する機能を提供する。実行可能性はシ ミュレーションの解析体系や出力データに依存する。

Message 層: Cognitive 層によって作成されたデータ解析プ ロセスの内容を実行計算機へ伝えるためのメッセージを作 成する機能を備える。また，実行計算機上に存在する Application 層とのメッセージ通信のためのインフラを整備 する。さらに, Application 層による解析結果を受け取り, Cognitive 層に伝える機能を備える。

Application 層 : データ解析プロセスメッセージに従って, 実行エンジンを用いてデータ解析を実施する。実行エンジ ンには各語彙に対応したリソース・プロパティがあらかじ 


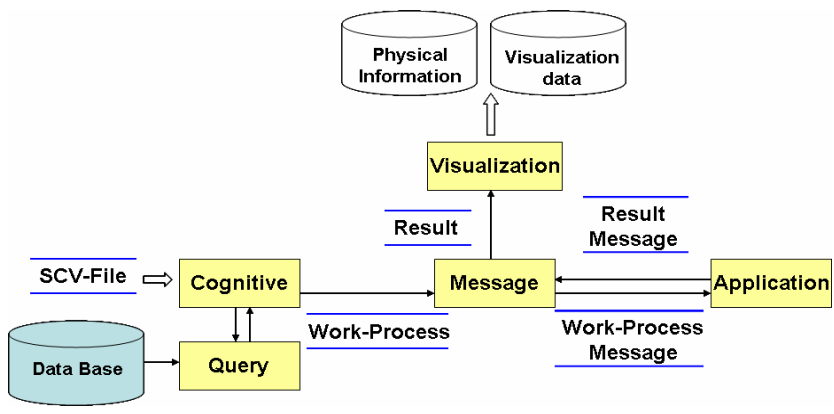

Fig. 5. System configuration for CDAS

め実装されており，データ解析プロセスメッセージに従つ て，それらを用いて処理を実行する。さらに，Message 層を 介して Visualization 層に処理結果を伝える機能も提供する。

Visualization 層 : Application 層によって把握・抽出された物 理的・工学的情報から, 知見フレームを用いて抽出された 科学的知見情報を出力する機能を備える。加えて, その科 学的知見情報が存在すると推測される領域に対する可視化 用データも同時に出力する機能を併せ持つ。

\section{5. 数値流体シミュレーション結果への適用}

本章では提案手法に基づいて構築されたデータ解析シス テムを実際の数值流体シミュレーション結果の解析に適用 することで，CDAS の動作検証を実施する。

$\langle 5 \cdot 1\rangle$ 解析対象例 本手法の有効性を検証するた め, 高稠密炉心内（Figure 6）の気液二相流数值シミュレー ション結果 ${ }^{(6)}$ に適用した。高稠密炉心は水冷却増殖炉にて 1.0 以上の転換比を達成するため, 燃料棒をギャップ $1 \mathrm{~mm}$ 程度の三角配列した炉心である。炉心燃料集合体あたりの 燃料棒本数が現行原子炬に比べて極めて大きいが，その内 部流動に関する知見が不足しており，その熱流動解析は重 要である。特に燃料棒周辺のドライアウト現象は炉心の限 界熱出力を決定する重要な因子であり，工学的に有意味な 解析対象である。この解析対象は総格子数が 5600 万格子で あり，実行時に必要なメモリは約 170GB 以上と極めて大規 模な数值シミュレーションである。

$\mathrm{CDAS}$ への入力用結果データは KGT 社の可視化ソフト ウェアAVS Express の 3 次元構造格子の形式を採用した。本 実装ではシミュレーション結果はこのAVS Express の 3 次 元構造格子型形式に統一している。また, リソースとプロ パティの実装は C++を用いた。

〈5·2〉 データ解析プロセスの記述例 Figure 7(a)に 今回実装した科学概念語彙で記述されたデータ解析プロセ スを示す。このプロセスはある壁面上に存在する液膜が破 断している領域を検出するように記述されている。

1 行目の科学的知見リソースは「破断」を「発見」すると いう概念を示すリソースであり，結合した物理量分布リソ 一ス（3 行目）の物理量情報を読み込み，その物理量が 0 と なる地点を検出するアルゴリズムをメソッドとして持つ。 「破断」概念を観測する領域は科学的指標が保持している観

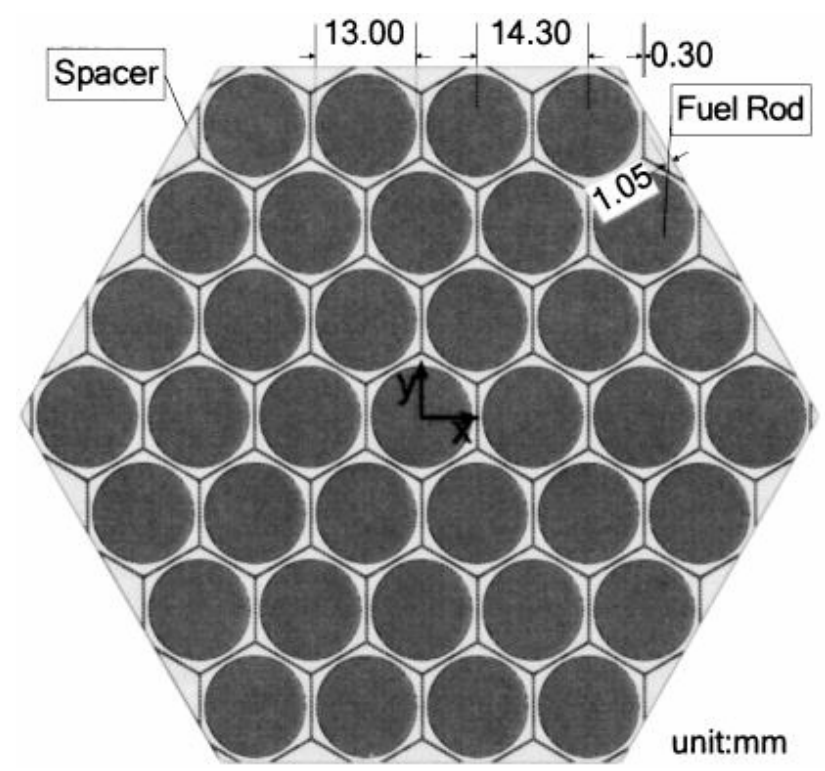

Fig. 6. Analysis Domain of the numerical simulation

測領域情報から知ることができる。さらに科学的指標が持 つ観測対象概念ラベル（ここでは液膜厚さ）を利用するこ とで「液膜破断」という情報を生成することができる。

2 13 行目においては科学的指標が示されている。3 行目 の物理量分布リソースは「厚さ」概念を示すリソースであ る。このリソースは<pd:region>によって指定された壁面領 域を始点とし, その壁面の地点から鉛直方向に物理量を探 索し，<pd:condition>によって指定された物理条件を満たす 地点を終点として，その始点・終点間の距離を厚さとして 定義するアルゴリズムをメソッドとして持つ。また，観測 された液膜厚さ分布を観測結果, 液膜厚さという物理概念 を観測対象概念ラベルとして保持する。5 行目において設定 されている壁面は, 炉内中心に位置する燃料棒の存在領域 情報が別に定義されている。物理条件としては 8〜10 行目 において気相体積率が 1.0 に等しいと設定した。

14〜16 行目においては科学的状態が示されている。本デ 一タ解析プロセスでは「上流・中流・下流」という流域情 報を用いている。この情報は「上流」「中流」「下流」とい う観測位置概念ラベル, それらの物理的意味がどの領域に 設定されているかを示す意味分布情報によって保持されて いる。

「破断」が検出された領域が科学的状態で定義された「上 流」「中流」「下流」のどの領域に属するのかを分析するこ とで，液膜破断が最も多く検出される領域を特定すること ができる。これらの特徵情報は「発見」に関する知見フレ 一ムによって一つの科学的知見情報に統合される。以上に よって「液膜破断が中流域に最も多く発生している」とい う知見情報を得ることができる。

本検証では「測定」に関する知見情報も確認している。 Figure 7(b)には「最大空間平均 Void 率 (気相が空間に占める 割合）は原子炉燃料棒支持用スペーサ（以下，スペーサ） の後方領域において 0.74 である」に関する記述例を示した。 
<scv:Description rdf:about="urn:Detection:Break">

$<$ sp:target $>$

$<$ scv:Description

rdf:about="urn:Physical_Distribution:Thickness">

$<$ pd:region $>$

$<$ scv:Description rdf:about="urn:Boundary:Wall" />

$</$ pd:region $>$

$<$ pd:condition $>$

$<$ scv:Description

rdf:about="urn:Physical_Condition:VOF">

9

10

11

12

13

14

15

16

17

(a) Example of a data analysis process which detects breakdown of liquid film around a fuel rod

$<$ scv:Description

rdf:about="urn:Detection:Max_SpaceAverage">

$<$ sp:target $>$

$<$ scv:Description

rdf:about="urn:Physical_Distribution:VOF" />

4

$</$ sp:target $>$

$<$ sp:status $>$

$<$ scv:Description

rdf:about="urn:AnalysisDomain:Spacer_Region" / >

$</$ sp:status $>$

$8</$ scv:Description $>$

(b) Example of a data analysis process which measures maximum value of average void fraction in analysis domain

$<$ scv:Description rdf:about="urn:Detection:Max">

$2<$ sp:target $>$

$3<$ scv:Description

rdf:about="urn:Physical_Distribution:Z-Velocity" />

$</$ sp:target $>$

$<$ sp:status $>$

$<$ scv:Description

rdf:about="urn:AnalysisDomain:Flow_Region" />

$</$ sp:status $>$

$8</$ scv:Description $>$

(c) Example of a data analysis process which measures maximum value of z-direction velocity in analysis domain

Fig. 7.
この例の場合, 1 行目は測定対象が空間平均の最大值である ことを示したリソースである。2〜4 行目において科学的指 標として気相率分布リソースが，5〜7 行目においてはスペ 一サ領域（スペーサ前方，スペーサ内，スペーサ後方）リ ソースが示されている。気相率分布リソースはデータファ イルを読み込むメソッドとその指定された領域の物理量分 布を観測するメソッドを持ち，観測結果や観測対象概念ラ ベルを保持するデータ構造を持っている。スペーサ領域リ ソースはスペーサ前方, スペーサ内，スペーサ後方という 観測位置概念ラベルとそれらの物理的意味がどの領域に設 定されているかを示寸意味分布情報を保持している。これ らの情報を用いて前述の知見情報が生成される。同様に, Figure 7(c)には「鉛直方向最大速度は中流域において $32.0 \mathrm{~m} / \mathrm{s}$ である」の記述例を示した。今回，「測定」「発見」に関す る知見情報は合計 32 種類確認している。

〈5·3〉検証結果 Figure 8 に今回記述されたデータ 解析プロセスによってシステムから出力されたデータ解析 結果のメッセージファイル内容を示す。本解析結果による と, 燃料棒周辺における「液膜破断が中流域に最も多く発 生している」という情報が示されている。加えて, 全体の 液膜破断のどの程度の割合がこの領域に存在しているの か, また, 中流域の定義領域の始点・終点が示されている。 さらに, この領域における気相・液相分布の可視化用ファ イルも同時に出力される。

ここで示した知見情報は極めて単純な形式をしている が, 全て「科学的指標」「科学的状態」「定性的・定量的特 徵」の情報を含んでおり, 科学的に有用な知識へと結びつ く情報である。例えば今回メッセージとして示された液膜 破断に関する情報から，中流域に何らかの理由によって多 数の液膜破断が生成される要因があると推測することがで きる。すなわちこれは科学的知見となり得る。実際, 本解 析体系の中流域には燃料棒を支えるためのスペーサが存在 しており，このスペーサの影響によって擾乱が発生し，液 膜破断が生成されているものと考えられる。

〈5・4〉有効性の検討 3 章で述べたように, 本研究で は科学的知見を「科学的指標」「科学的状態」「定性的・定 量的特徴」によって構成されるものとしている。これは「何 が (科学的指標)」「いつ・どこで (科学的状態)」「どうな った（定性的・定量的特徴）」と言い換えることができる。 どれほど複雑な科学的知見もその基本的な構造は「何が」 「いつ・どこで」「どうなった」という情報に集約できると 考えられる。本論文で提案している知見フレームはこのよ

Most Break of Thickness is detected in midstream region percentage of total : 0.53754

start point of midstream $(\mathrm{x}, \mathrm{y}, \mathrm{z})=0.046725,0.041475,0.023625$

end point of midstream $(\mathrm{x}, \mathrm{y}, \mathrm{z})=0.046725,0.041475,0.048375$

Fig. 8. Analysis result output from CDAS 
うな基本的構造をもつ科学的知見に対応できると言える。

今回の検証結果により, 本研究で提案した科学概念語彙 のデータ構造は, 数值流体シミュレーションを用いた科学 研究において一般的に用いられる科学的指標（例えば，平 均 Void 率分布, 3 次元速度分布, 液膜など), 科学的状態 (流 入口からの距離, 上流・中流・下流など), 定量的・定性的 特徵（最大值, 最小值, 液膜破断など）を十分に表現でき ることを示した。また，これらのデータ構造に立脚した知 見フレームにより科学的に重要な知見情報の生成が可能で あることを示した。

今回は 32 種類の知見情報を確認したが, 語彙を拡張する ことで同様の構造をもつ多様な知見情報を抽出することも できる。例えば, 今回の検証では物理量として速度, 圧力, 気相体積率を用いたが，これ以外にも温度，エネルギーな どの物理概念を新たに定義することが可能である。また，

観測対象も「上流・中流・下流」,「スペーサの前方, 後方」 などに限らず，「ある構造物の壁面上」「流入口付近」など 必要に応じて新しい物理的意味をもった領域を同様のしく みで定義することが可能である。これにより，ユーザが対 象とする解析体系に適した知見情報の生成・抽出に対応し ていく。

以上から, 提案手法は科学的知見情報をシステムに認識 可能な形式で表現するうえで有効な技術となり得ると考え られる。これらの科学的知見情報を比較・統合し科学的な 知識とするための技術は今後の検討課題である。

〈5.5〉従来の研究との比較 オントロジーや RDF ・ OWL などのセマンティックウェブ技術を用いたデータ処理 手法はこれまでにも多数提案されている(9)(10)。例えば, 分子 生物学の分野では遺伝子の機能を記述するための Gene Ontology (GO) を定義しており ${ }^{(9)}$, Gene Ontology Consortium によって, GO を用いて様々な遺伝子機能に関する情報が記 述された RDF-XML データファイルが配布されている。太 陽地球系物理学分野では, 物理観測データを統一的に記述 するために SPASE (SpacePhysics Archive Search and Extract) による XML Schemaを用いたメタデータ仕様策定が試みら れている ${ }^{(10)}$ 。この仕様では観測データの種類・観測者・保 存場所や施設などを記述することができ, 研究者は必要な データを検索し，それらのデータを使用することができる。 これらは抽出されたデータの解析を人間の手によって行 い, 得られた解析結果に対してメタデータを付与すること でデータの共有・検索の効率化を実現している。

それに対し, 本研究が対象としている大規模・複雑な数 值シミュレーションの出力データは, データ解析を実施し, 物理的に有意味な情報を抽出すること（解析結果にメタデ 一夕を付与すること）そのものが困難である。本提案手法 の特徴は, 従来の手法がデータのみを対象としてオントロ ジー上で意味を定義しているのに対し，本手法はデータの 処理プロセス（例えば, 物理量分布測定, データマイニン グ，統計処理など）もまたオントロジー上で物理的意味が 定義されている。これにより, データ解析結果にもオント
ロジー的な意味が付与されることになる。結果, データ解 析結果に対してメタデータが自動的に付与されることにな り, システムはそのメタデータから解析結果の物理的意味 を認識することが可能となる。

\section{6. 結言および今後の課題}

著者らはデータ解析システムに物理的意味を認識させる ことを目的とした科学概念語彙モデルの開発を試みてい る。これまでの科学概念語彙モデルでは従来の「液膜破断 が存在する」という単純な物理的・工学的情報しか表現で きなかった。本論文ではより複雑な物理的・工学的情報を 扱うために以下のことを行った。

(1) 科学的知見が科学的指標, 科学的状態, 定量的・定 性的特徴によって構成されるという科学的知見モデルを提 案した。

(2) 科学的指標 - 科学的状態 - 定量的 - 定性的特徽を表 現するための具体的なデータ構造を提案した。

(3) 科学的知見情報を構成するための「知見フレーム」 を提案した。

これらの手法を実際の数值シミュレーション結果に適用す ることで「液膜破断が中流域に最も多く発生している」の ように, 物理的 - 工学的現象における定量的・定性的特徽 がどこに・どの程度存在しているのかまで表現できること を示した。以上より, 本手法によって, さらに複雑な知見 情報をシステムによって数值的に扱うことができるように なったと言える。

今後の課題として, 本手法の適用例を増やし, 知見情報 の表現力を定量的に評価していく必要がある。また, 解析 体系が複雑になれば, 大量の知見情報が解析対象候補にな るため, 全てのデータ解析プロセスを実施すると膨大な解 析時間が必要となってしまう。よって, より重要と考えら れる知見情報を抽出するプロセスから優先的に実行するし くみが必要となる。

\section{謝 辞}

本システムの検証で用いた数值流体シミュレーションは 原子力研究開発機構 原子力基礎工学研究部門の吉田啓之 氏，三沢丈治氏の多大な協力を得た。ここに記して感謝す る。

(平成 21 年 11 月 10 日受付, 平成 22 年 3 月 3 日再受付)

\section{文献}

(1) The Next-Generation Supercomputer R\&D Center (NSC), http://www.nsc.riken.jp/index-eng.html

(2) C. Kino, Y. Suzuki, A. Nishida, N. Kushida, S. Hayashi, and N. Nakajima : "Concept design of Cognitive methodology based Data Analysis System", Trans. JSCES, Paper, No.20080018 (2008) (in Japanese) 木野千晶・鈴木喜雄・西田明美・櫛田慶幸・林 幸子・中島憲宏 : 「認能力を備えたデータ解析システムの概念設計」, 日本計算工学会 論文集＼cjkstart論文番号：20080018 (2008) 
(3) C. Kino, Y. Suzuki, N. Kushida, A. Nishida, S. Hayashi, and N. Nakajima : "Development of Cognitive Methodology based Data Analysis System", High Performance Computing on Vector Systems 2008, M. Resch, S. Roller, K. Benkert, M. Gelle, W. Bez, H. Kobayashi, T. Hirayama (Eds.) Springer-Verlag Berlin Heidelberg, pp.89-97 (2008)

(4) C. Kino, Y. Suzuki, H. Takemiya, and N. Nakajima : "Cognitive Methodology based Data Analysis System", Proc. The 71st National Convention of IPSJ, 4D-3 (2008) (in Japanese)

木野千晶・鈴木喜雄・武宮 博・中島憲宏 : 「認識能力を備えたデー 夕解析システム」, 情処学会第 71 回全国大会講演論文集 4D-3 (2008)

(5) World Wide Web Consortium (W3C): Resource Description Framework, http://www.w3.org/RDF/

(6) H. Yoshida, T. Nagayoshi, Y. Ose, K. Takase, and H. Akimoto : "Investigation of Water-Vapor Two-Phase Flow Characteristics in a Tight-Lattice Core by Large-Scale Numerical Simulation", Trans. the Atomic Energy Society of Japan, Vol.3, No.3, pp.233-241 (2004) (in Japanese)

吉田啓之・永吉拓至 - 小瀬裕男・高瀬和之・秋本 肇 :「大規模シミ ユレーションによる稠密炉心内気液二相流特性の解明 改良界面追 跡法を用いた二相流直接数值解析手法の開発」, 原子力学会論文集 Vol.3, No.3, pp.233-241 (2004)

(7) D. L. McGuiness and F. Harmelen : "OWL Web Ontology Language Overview", 2004-02-10 W3C Recommendation, http://www.w3.org/TR/owl-features/

(8) R. Fielding, U. C. Irvine, and L. Masinter : "Uniform Resource Identifiers (URI): Generic Syntax", RFC2396, RFC Standards Track, The Internet Society (1998)

(9) The Gene Ontology Consortium : "Gene Ontology: Tool for the Unification of Biology”, Nature Genetics, Vol.25, pp.25-29 (2000)

(10) Space Physics Archive Search and Exchange (SPASE) Consortium: Space and Solar Physics Data Model Version:1.3.4, http://www.spase-group.org/ 2009

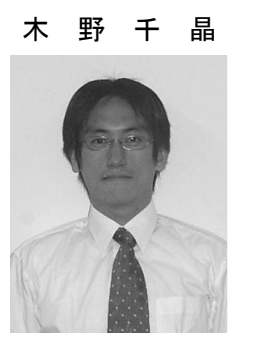

（非会員） 1978 年 10 月 27 日生。2007 年 3 月 京都大学大学院工学研究科原子核工学専攻博 土後期課程修了。2007 年（独）日本原子力研究 開発機構入社。知能情報処理を用いたデータ解 析システムの研究に従事。情報処理学会会員。

鈴木 喜 雄

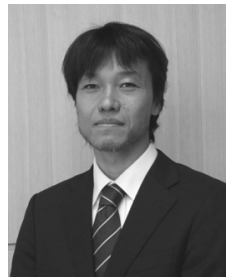

（非会員）1996 年 3 月広島大学大学院博士課程 卒業。理学博士。日本学術振興会特別研究員 (核 融合科学研究所理論シミュレーション研究セ ンター所属), 日本原子力研究所博士研究員 (那 珂研究所炉心プラズマ研究部プラズマ理論研 究室所属), 科学技術特別研究員 (那珂研究所 炉心プラズマ研究部プラズマ理論研究室所属） を経て, 2002 年に日本原子力研究所入所。現在, 原子力情報基盤システム研究総括。可視化技術の研究開発に従事。

武 宮 博 (非会員) 1986 年 3 月東北大学大学院理学研究

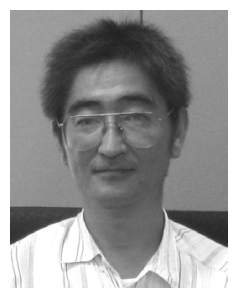

科修士課程修了。1989 年同大学大学院理学研究 科博士課程中退。同年 日立東日本ソリューシ ヨンズ (株) 入社。2003 年 産業技術総合研究 所グリッド研究センター（派遣）。2008 年 7 月 (独）日本原子力研究開発機構入社。システム 計算科学センター 高度計算機技術開発室室 長。情報処理学会会員。 